\title{
CLINICAL INVESTIGATION OF BONE METABOLISM IN SPINAL CORD LESIONS
}

\author{
By Alex Chantraine, M.D. \\ Service de Physiothérapie, Hôpital de Bavière, Université de Liège
}

THE metabolism derangements in patients with spinal cord lesion as well as cerebral trauma have been investigated in terms of serum and urinary levels of calcium, phosphorus, creatine, creatinine, nitrogen and ketosteroids. The metabolic changes that occur in these kinds of patients (in the course of their trauma or in chronic phase) have been extensively reviewed (Freeman, 1949; Cooper et al., I950; O'Connel, I953, Wyse and Patee, I954; Kapland et al., I966). These patients present below the level of their neurological lesion an osteoporosis; it is not infrequent to observe in those a para-articular osteopathy.

Recently Klein (I966) has described a sequential study of the metabolic response of the skeletal system to acute paraplegia. He reported rapid and large increase of urinary calcium and hydroxyproline excretion as well as gradual increase of serum alkaline phosphatase activity.

Kinetic study of calcium metabolism by means of $45-\mathrm{Ca}$ was introduced and was revealed to be the preferred method as an index of bone metabolism (Bauer et al., I957; Bronner et al., I963; Aubert et al., 1965). This analysis allows to express in terms of rate ( $\mathrm{mg}$. $\mathrm{Ca} / 24 \mathrm{hr}$.) the calcium transfer in the body and mostly calcium deposition in bone, generally considered as a measure of skeleton anabolism. The measurement of total urinary hydroxyproline excretion has proved useful in the study of various bone disorders and in fracture healing (Klein et al., 1962; Dull, I963). Hydroxyproline is a specific amino acid of the connective tissue protein (collagen and elastin) and its amount measured in the urines represent a good index of the catabolism of these proteins.

The present report describes a study of the metabolism of the connective tissue in patients with spinal cord lesion. Some of these patients have been followed for 3 years from the beginning of their cord injury. We have also considered in this study patients with cerebral trauma and paraplegia due to poliomyelitis. Urinary calcium and hydroxyproline as well as kinetic studies with $45-\mathrm{Ca}$. were used as indices of bone metabolism.

\section{METHOD}

Calcium metabolism was investigated with a technique inspired from Aubert et al. (1960). This method is based on a mathematical analysis of the plasma specific radioactivity curve of calcium after an intravenous injection of $45-\mathrm{Ca}$. Calcium in the blood is considered as a system in dynamic equilibrium state (fig. I), a central calcium pool (P) which receives calcium from the skeleton (Vo-) and the food (Vi) absorbed from the intestine (Va) and loses it to the skeleton $(\mathrm{Vo} \pm)$, the urine $(\mathrm{Vu})$ and the faeces $(\mathrm{Vf})$. Various analysable exchange processes occur within $\mathrm{P}$, which is made up for four compartments $\mathrm{M}, \mathrm{MI}, \mathrm{M}_{2}$ and $\mathrm{M}_{3}$ 
(fig. 2) respectively identified with blood calcium extracellular fluid calcium, softtissue calcium and bone-exchangeable calcium. The total calcium loss from the pool $\left(\mathrm{V}_{\mathrm{T}}\right)$ is equal to the sum of $\mathrm{Vo}+, \mathrm{Vu}$ and $\mathrm{Vf}$. In the absence of reliable determination of calcium balance, we have adopted, for our study, an experimental scheme which is a simplified form that has been repeated several times in different patients. The patients have been kept under gelatin-free and low content-calcium diet ( \pm I00 mg. per day). The endogenous of faecal calcium excretion has been assumed to remain at the constant level of $100 \mathrm{mg}$. per day. All subjects receive intravenously Io microcuries of $45-\mathrm{Ca} \mathrm{Cl}_{2}$ of high specific activity at the beginning of the test. Blood samples are collected at 24, 48, 72, 98 and I44 hours following the injection and the specific radioactivity of the calcium has been measured.

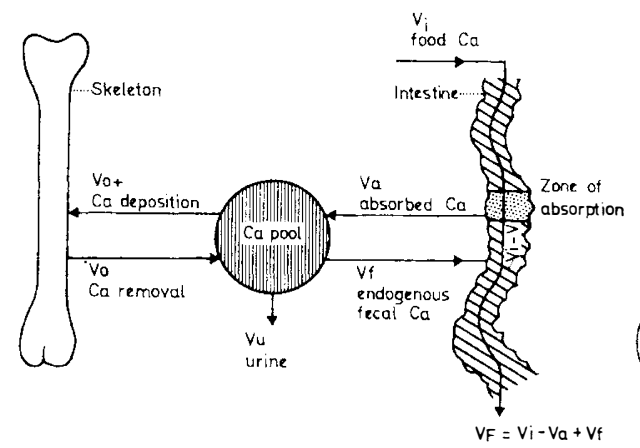

FIG. I

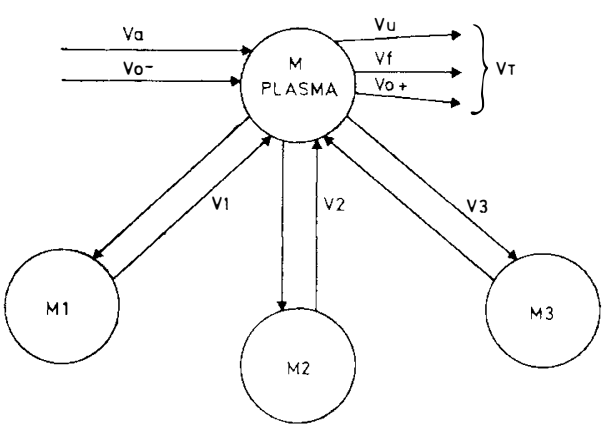

FIG. 2

Fig. I.-Scheme of calcium metabolism.

Fig. 2.-Model of exchangeable calcium pool, adapted from Aubert \& Milhaud (1960).

The simplified technique allows for the measurement of the size of the calcium pool $(\mathrm{P})$ and the calcium loss from the pool $\left(\mathrm{V}_{\mathrm{T}}\right)$. Urinary calcium is the average calcium lost during the first, the fourth and the sixth day. Hydroxyproline is also measured with the Prokop technic from the same urine samples.

\section{OBSERVATIONS}

Fifty-nine patients with neurological lesion - 33 paraplegias, Io quadriplegias, Io cerebral traumas and 6 poliomyelitis or similar lesion (anterior horn cells) underwent this metabolic study. These patients ( 42 males and 17 females) varied in age from 16 to 72 years.

The metabolic studies were started as soon as possible after the onset of paralysis in the majority of cases. However, in some we were able to begin only several months following the neurological lesion. Most patients were followed for at least I year and some of them are now under study for more than 3 years.

The results of these metabolic studies are compared to the results obtained in a group of 28 normal people ( 12 males and 16 females) of similar age range (I9 to 69). Statistical evaluations have been calculated in IBM 7.040 at the Mathematics Centre of Liège University, using a programme in Fortran language. 


\section{RESULTS}

In our normal population, we have found that hydroxyprolinuria varies between 26 and $38 \mathrm{mg}$. per day, as seen in Table I.

In poliomyelitis we observed a very low level of hydroxyproline excretion, lower than seen in normal (Table II). This low rate does not vary with the time and shows no difference whatever the age and the sex.

TABLE I

\begin{tabular}{|c|c|c|c|c|}
\hline \multicolumn{3}{|c|}{ Hydroxyprolinuria in Normal (Mean) } \\
\hline & \multicolumn{2}{|c|}{ Females } & \multicolumn{2}{c|}{ Males } \\
\hline Age & No. & mg./24 hr. & No. & mg./24 hr. \\
\hline 20-30 years & 6 & 33.3 & 6 & 38 \\
3I-50 years & 7 & 26.8 & 4 & 35 \\
5I-70 years & 3 & 28.6 & 2 & 33 \\
\hline & I6 & 29.5 & I2 & 37.6 \\
\hline
\end{tabular}

TABLE II

\begin{tabular}{|c|c|c|c|c|c|c|c|}
\hline \multicolumn{9}{|c|}{ Hydroxyprolinuria in Poliomyelitis } \\
\hline No. & Age & Sex & $\begin{array}{c}\text { Duration } \\
\text { (Years) }\end{array}$ & I year & 2 years & 5 years & 9 years \\
\cline { 1 - 5 } & & & & & & \\
\hline I & 38 & F & 5 & - & $24 \cdot 5$ & 22 & - \\
2 & 39 & F & IO & - & - & - & 2 I \\
3 & 25 & F & I0 & - & - & - & 24 \\
4 & 66 & M & 9 & - & - & - & 24 \\
5 & 34 & M & 5 & - & - & 24 & - \\
6 & 30 & F & 2 & 28 & 23 & - & - \\
\hline
\end{tabular}

In all the patients with spinal cord lesion we have found a very good correlation between urinary hydroxyproline, calcium accretion rate $(\mathrm{Vo}+)$, calciuria $(\mathrm{Vu})$ and total calcium loss from the pool ( $\mathrm{V}_{\mathrm{T}}$ ) (figs. 3 to 5 ). Therefore, we can assume that urinary hydroxyproline excretion represents an excellent picture of bone metabolism. Furthermore, it is easier and safer for the patients to repeat the hydroxyproline analyses. Such a test has been repeated at close intervals of time, starting shortly after the spinal cord lesion and sometimes going up to 3 years. 


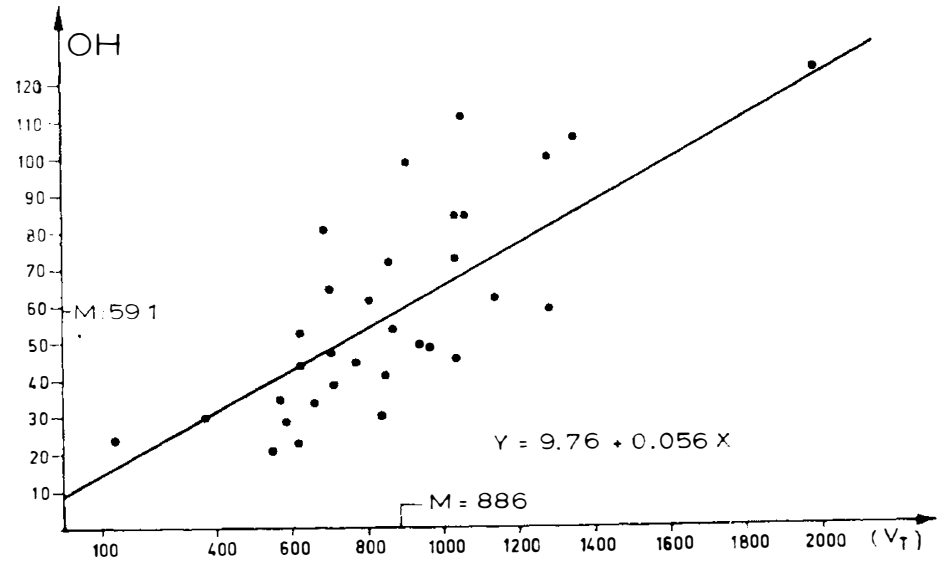

FIG. 3

Relation between urinary hydroxyproline excretion and total calcium loss from the pool $\left(V_{T}\right)$.

FIG. 4

Relation between urinary hydroxyproline excretion and calcium accretion rate $(\mathrm{Vo}+)$.
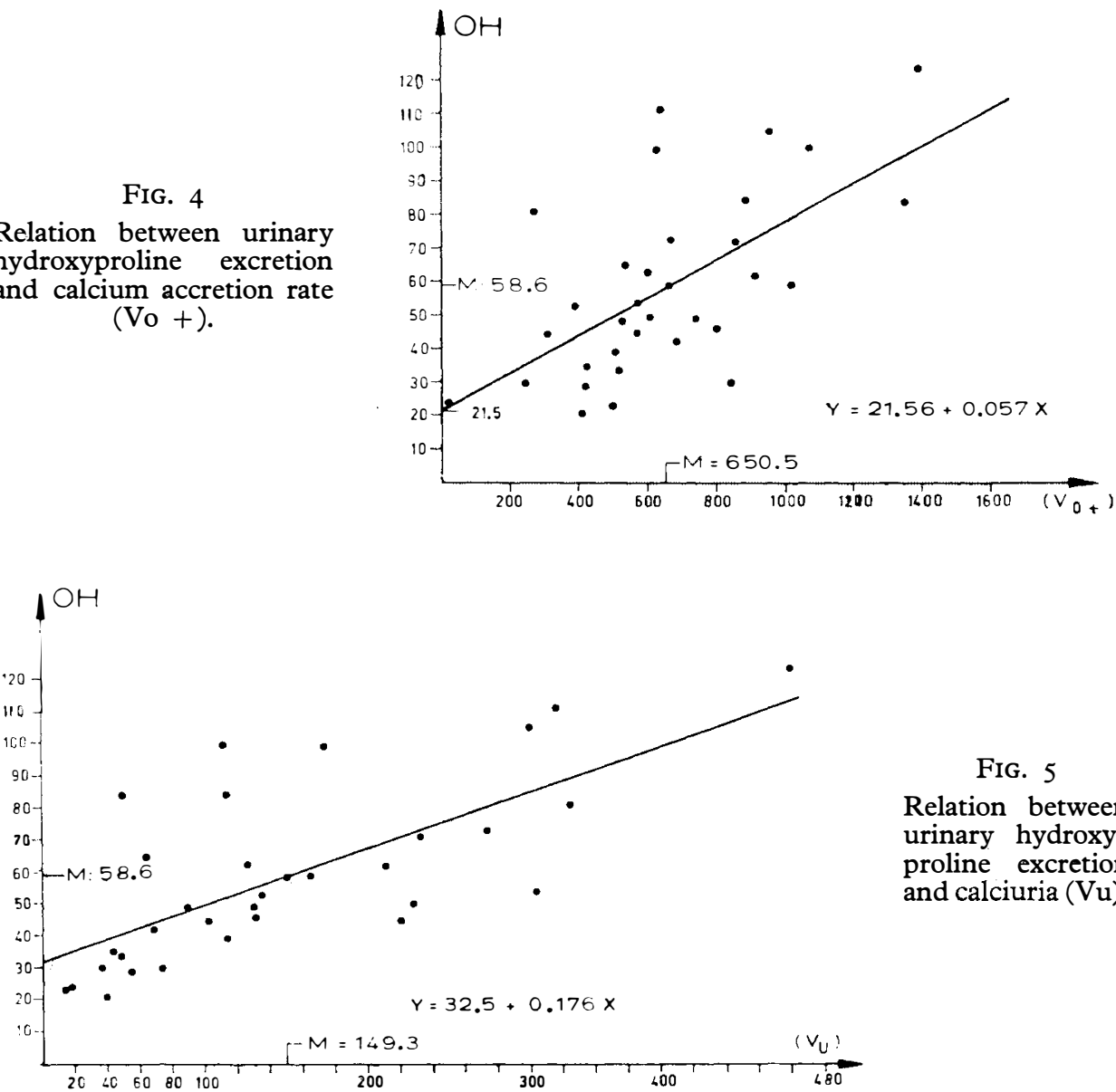

FIG. 5

Relation between urinary hydroxyproline excretion and calciuria $(\mathrm{Vu})$. 
In paraplegics, quadriplegics and cerebral traumas, urinary hydroxyproline excretion is initially very high up to and frequently above Ioo $\mathrm{mg} . / 24 \mathrm{hr}$. during the first weeks following the lesion.

We have generally observed, that the total calcium loss from the pool $\left(V_{T}\right)$ seems to be higher after the onset of paralysis than in normal people of the same age and sex. The value of $\mathrm{V}_{\mathrm{T}}$ decreases with the time. The calciuria $(\mathrm{Vu})$ and the bone calcium deposition $(\mathrm{Vo}+)$ varies similarly.

If we compare the mean excretion rate of hydroxyproline in these three groups of patients, we can observe that the level is within the same range and that it is significantly higher than that of the normal (Table III).

The evolution in time of the excretion of hydroxyproline in each group of patients is very similar (Table III). Examples will illustrate the relation between urine hydroxyproline excretion and the time in patient with paraplegia and with quadriplegia (figs. 6 and 7). This phenomena is represented by a regression line going down with a declivity of -0.09 to $-0.08 \mathrm{mg}$. of hydroxyproline per day. The error probability on this regression line is very small $(\mathrm{P}<0.0005)$. These results show that the urinary hydroxyproline excretion in patients with spinal cord lesion or cerebral traumas is initially very high and decreases with the time up to values still above normal, even after 3 years.

We have not yet found any correlation with associated pathological status such as fracture or para-articular osteopathy. There seems to be no statistical difference in the excretion of hydroxyproline related to the aetiology of the spinal cord lesion (traumatic or tumour) or the level of the lesion except if there is only an alteration of the lower motor neuron.

\section{DISCUSSION AND CONCLUSION}

The good correlation that exists between urinary hydroxyproline excretion, total calcium loss from the pool, calciuria and bone calcium accretion rate measured by kinetic analysis in patients with paraplegia, quadriplegia and cerebral trauma indicates that the measurement of hydroxyproline in the urines is a good test of bone metabolism.

In these patients we have found that the excretion of hydroxyproline is initially very high and decreases with the time. The values observed in those patients remain higher than in normal subjects of comparable age and sex for a long period of time following the onset of neurological lesion.

In all these patients where osteoporosis below the neurological lesion level is the rule, the increased excretion of hydroxyproline indicates a larger than normal catabolism of bone. Bone anabolism as measured with $\mathrm{Ca}-45(\mathrm{Vo}+)$ is initially normal or slightly elevated. It seems that the overall bone turnover rate is increased in these patients. The osteoporosis would result from a catabolism more increased than the anabolism.

\section{RÉSUMÉ}

Le dosage de l'hydroxyproline s'avère être un bon test du métabolisme osseux. Il semble que chez les malades avec une paraplégie, quadriplégie, ou un traumatisme crânien que l'éxcrétion d'hydroxyproline est, au début, très élevée et diminue avec le temps. Les valeurs observées chez ces malades demeurent plus élevées que chez des sujets normaux comparables, ceci pandant assez longtemps après le début de l'atteinte neurologique. Chez 
TABLE III

\begin{tabular}{|l|c|c|c|c|c|c|}
\hline \multicolumn{8}{|c|}{ Hydroxiprolinuria (mg./24 hours) (Mean) } \\
\hline & $\begin{array}{c}\text { Ist } \\
\text { month }\end{array}$ & $\begin{array}{c}\text { 3rd } \\
\text { month }\end{array}$ & $\begin{array}{c}\text { 6th } \\
\text { month }\end{array}$ & $\begin{array}{c}\text { I2th } \\
\text { month }\end{array}$ & $\begin{array}{c}\text { I8th } \\
\text { month }\end{array}$ & $\begin{array}{c}\text { 24th } \\
\text { month }\end{array}$ \\
\hline Paraplegia & 94 & 79 & 82 & 57 & 68 & 39 \\
Quadriplegia & 97 & 97 & 85 & 64 & 64 & 40 \\
Cerebral trauma & - & 97 & 79 & 52 & 54 & - \\
\hline
\end{tabular}

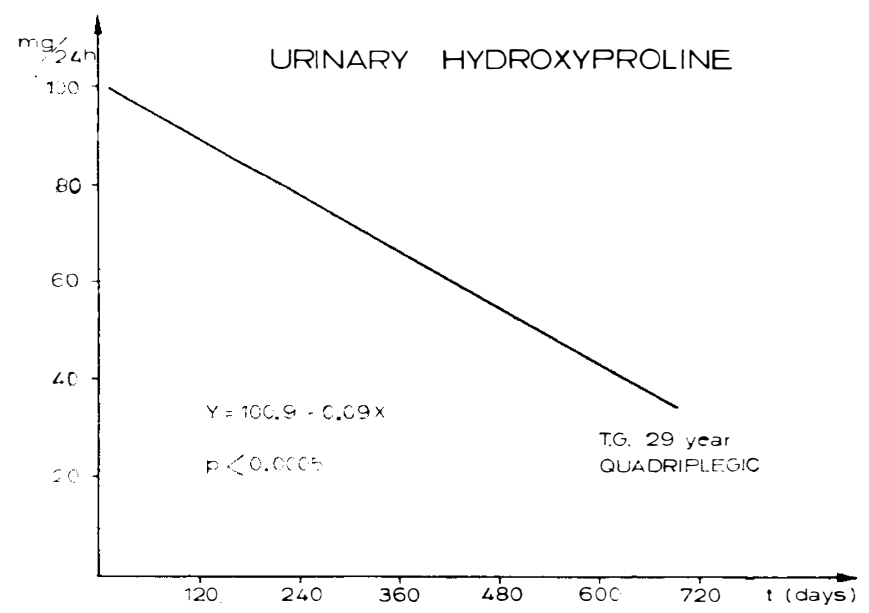

FIG. 6

Relation between urinary hydroxyproline excretion and number of days during which patient has been investigated.

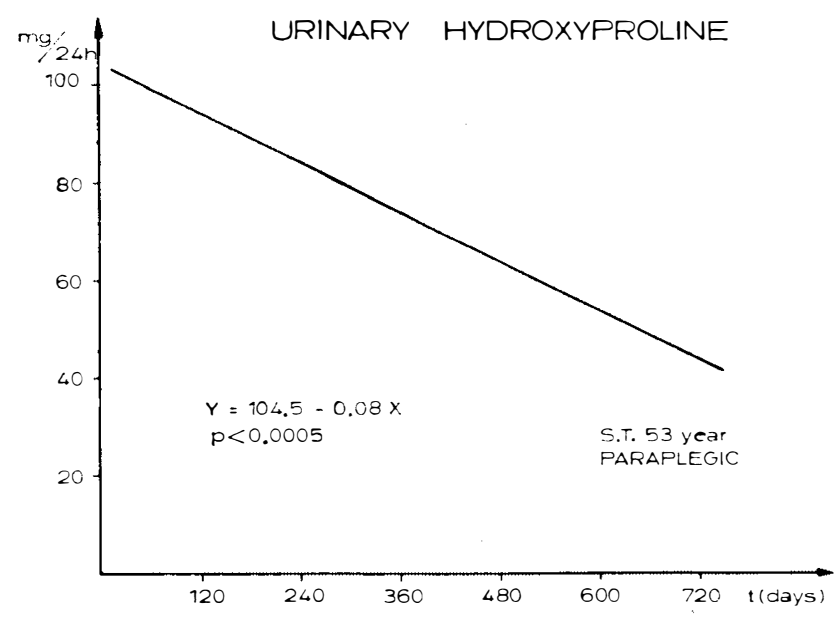

Fig. 7

Relation between urinary hydroxyproline excretion and number of days during which patient has been investigated. 
ces malades, où l'ostéoporose sous-lésionnelle est la règle, l'augmentation d'excrétion de l'hydroxyproline indique une augmentation du catabolisme osseux. L'anabolisme osseux est mesuré avec du calcium 45 et, au début, élevée ou légèrement élevée. Il semble que les échanges calciques soient plus élevés chez ces malades. L'ostéoporose résulterait d'un catabolisme augmenté par rapport à l'anabolisme.

\section{ZUSAMMENFASSUNG}

Die gute Korrelation, die zwischen Hydroxyproline Ausscheidung, totalem Calciumverlust, Calciuria und Wachstumrate von Knochencalcium besteht, gemessen bei kinetischer Analyse an spinal und cerebral Gelähmten zeigt, dass die Messung von Hydroxyproline ein guter Indikator für den Knochemetabolismus ist.

Wir fanden, dass bei diesen Patienten die Ausscheidung von Hydroxyproline in Vergleich mit Normalen anfangs hoch ist und dann allmählich abnimmt.

In all diesen Patienten, wo Osteoporosis unterhalb der neurologischen Läsion die Regel ist, weist die erhöhte Hydroxyproline-Ausscheidung auf einen gesteigerten Katabolismus hin. Knochen-Anabolismus, gemessen bei Calcium $45(\mathrm{Vo}+)$ ist anfangs normal oder nur leicht erhöht. Die Osteoporosis ist das Resultat eines gesteigerten Katabolismus verglichen mit dem Anabolismus.

Acknowledgment. We are grateful to Professor C. Lapiere for his advice and assistance as well as for the facilities he gave us in his laboratory.

\section{BIBLIOGRAPHY}

Aubert, J. P. \& Milhaud, G. (I960). Biochim. biophys. Acta (Amst.), 39, I22.

Aubert, F. P., Moukhtar, J. S., Cherian, A. G. \& Milhaud, G. (I965). Université de Liège, pp. 359-373.

Bauer, G. C. H., Carlsson, A. \& Lindquist, B. (1957). Acta.Med. Scandinav., 158, I 43.

Bronner, F., Richelle, L. J., Saville, P. D., Nicholas, J. A. \& CobB, J. R. (I963). F. of Clinical Invest., 42, 6, pp. 898-905.

Cooper, I. S., Rynearson, E. H., MacCarty, C. S. \& Power, M. H. (I950). F. Clin. Endocrinol., 10, 858.

Dull, T. A., \& Henneman, P. H. (1963). New Eng. F. Med. 268, I32.

FreEMAN, L. W. (1949). Ann. Surg., 129, I77.

Kaplan, L., Powell, B. R., Grynbaum, B. B. \& Rusk, H. A. (1966). Comprehensive Follow-up Study of Spinal Cord Dysfunction and its Resultant Disabilities, pp. 56-64. Institute of Rehabilitation Medicine New York University-Medical Center.

Klein, L., Albertsen, K., \& CurTiss, P. H. Jr. (I962). Metabolism II, IO23.

Klein, L. R., VAN DEN Noort, St., \& Dejak, J. J. (I966). Medical Services fournal Canada, XXII, 7, pp. 524-533.

O’CONNELl, F. B. Jr., \& GARDNER, W. J. (1953). F.A.M.A. 1 53, 706.

Wyse, D. M., \& Pattee, C. J. (1954). Am. F. Med., I 7, 645. 